\title{
DIAGNOSIS OF WEST NILE NEUROINVASIVE DISEASE IN HUMANS
}

Ivana Hrnjaković Cvjetković1 ${ }^{12^{*}}$, Vesna Miloševićn ${ }^{1,2}$, Tamaš Petrović ${ }^{3}$, Dušan Petrić ${ }^{4}$, Gordana Kovačević ${ }^{1}$, Jelena Radovanov ${ }^{1}$, Aleksandra Patić1,2, Nataša Nikolić ${ }^{1,2}$, Sandra Stefan Mikić, ${ }^{2,5}$, Sofija Cvjetković ${ }^{2}$, Dejan Cvjetković ${ }^{5}$

${ }^{1}$ Institute of Public Health of Vojvodina, Novi Sad, Serbia

${ }^{2}$ Faculty of Medicine Novi Sad, University of Novi Sad, Novi Sad, Serbia

${ }^{3}$ Scientific Veterinary Institute "Novi Sad", Novi Sad, Serbia

${ }^{4}$ Faculty of Agriculture, University of Novi Sad, Novi Sad, Serbia

${ }^{5}$ Clinical Centre of Vojvodina, Novi Sad, Serbia

\section{Abstract}

West Nile virus (WNV) is arbovirus distributed all around the world. In humans, $80 \%$ of infection cases are asymptomatic. In $20 \%$ of infected people, a febrile self-limiting illness is reported. WNV has the potential for fatal neuroinvasive disease. In $1 \%$ of cases, the infection may result in neuroinvasive disease with permanent neurological consequences or death outcome. Neurological forms may vary presenting with encephalitis, meningitis, meningoencephalitis or acute flaccid paralysis. Outbreaks with neurological forms of WNV infection were recorded in different areas of Greece, Italy, Romania, Hungary and Serbia. During the period from 2013 to 2016, 114 samples of cerebrospinal fluid and 107 serum samples were taken from 114 patients suspected of WNV neuroinvasive disease (WNND). The presence of specific anti-WNV IgM and IgG antibodies in cerebrospinal fluid (CSF) and sera samples were tested by WNV IgM and IgG ELISA (Euroimmun, Germany). In addition, 48 samples of CSF or/and serum of people with suspected WNV infection were examined by commercial molecular tests - real time RT-PCR (WNV Real-TM, Sacace biotechnologies, Italy). The IgM antibodies against WNV were present in $25.4 \%$ (29/114) of CSF samples, and in $31.8 \%$ (34/107) of serum samples tested from 114 patients suspected of WNND. The IgG antibodies against WNV were detected in $3.5 \%(4 / 114)$ of CSF samples, and in $11.2 \%(12 / 107)$ of serum samples. The WNV RNA was detected by real time RT-PCR test in 7 out of $48(14.6 \%)$

${ }^{1 *}$ Corresponding author: ivana.hrnjakovic-cvjetkovic@mf.uns.ac.rs 
CSF or/and serum samples. In this study, detection of IgM antibodies in CSF is more frequent than detection of WNV RNA in CSF or serum samples. WNV RNA detection in CSF is confirmatory diagnostic test but has limited utility in the diagnosis of WNV neuroinvasive disease due to low viremia level at the time of clinical presentation of the disease. The limitations in the use of ELISA IgM test are linked to cross - reactivity among flaviviruses and long persistence of IgM antibodies in the serum and CSF.

Keywords: West Nile virus, ELISA IgM test, CSF, serum, real time RTPCR, WNV genome

\section{DIJAGNOSTIKA NEUROINVAZIVNE FORME BOLESTI ZAPADNOG NILA KOD LJUDI}

Ivana Hrnjaković Cvjetković ${ }^{1,2^{*}}$, Vesna Milošević ${ }^{1,2}$, Tamaš Petrović ${ }^{3}$, Dušan Petrić ${ }^{4}$, Gordana Kovačević ${ }^{1}$, Jelena Radovanov ${ }^{1}$, Aleksandra Patić ${ }^{1,2}$, Nataša Nikolić, ${ }^{1,2}$, Sandra Stefan Mikićc,5, Sofija Cvjetković ${ }^{2}$, Dejan Cvjetković ${ }^{5}$

${ }^{1}$ Institut za javno zdravlje Vojvodine, Novi Sad, Srbija

${ }^{2}$ Medicinski fakultet, Univerzitet u Novom Sadu, Novi Sad, Srbija

${ }^{3}$ Naučni institute za veterinarstvo "Novi Sad", Novi Sad, Srbija

${ }^{4}$ Poljoprivredni fakultet, Univerzitet u Novom Sadu, Novi Sad, Srbija

${ }^{5}$ Klinički centar Vojvodine, Novi Sad, Srbija

\section{Kratak sadržaj}

Virus zapadnog Nila (VZN) je rasprostranjen širom sveta. Kod ljudi u $80 \%$ slučajeva infekcija protiče asimptomatski. U $20 \%$ slučajeva infekcija se manifestuje kao blago febrilno oboljenje sa povoljnim ishodom. VZN može izazvati potencijalno fatalno neuroinvazivno oboljenje. U $1 \%$ slučajeva infekcija se može ispoljiti kao neuroinvazivna bolest sa neurološkim posledicama i smrtnim ishodom. Neurološke forme bolesti su različite i mogu se ispoljiti kao encefalitis, meningitis ili akutna flakcidna paraliza. Epidemije neuroloških formi oboljenja registrovane su u različitim područjima Grčke, u Italiji, Rumuniji, Mađarskoj i u Srbiji. U periodu od 2013. - 2016.god., 114 uzoraka likvora i 107 uzoraka krvnih seruma prikupljeno je od 114 pacijenata suspektnih na neuroinvazivnu bolest izazvanu VZN. Testovima WNV ELISA IgM i IgG (Euroimmun, Nemačka) testirani su svi uzorci seruma i likvora. Komercijalnim molekularnim testovima (WNV Real-TM, 
Sacace, biotechnologies, Italija) testirano je 48 uzoraka likvora i/ili seruma pacijenata suspektnih na neuroinvazivnu bolest izazvanu VZN. Antitela IgM protiv VZN dokazana su u 25,4\% (29/114) uzoraka likvora sakupljenih od 114 pacijenata suspektnih na neuroinvazivnu formu infekcije VZN uključenih u ovu studiju. Takođe, IgM antitela protiv VZN dokazana su u $31,8 \%(34 / 107)$ testiranih uzoraka seruma. IgG antitela protiv VZN dokazana su u 3,5\% (4/114) uzoraka likvora i u 11,2\% (12/107) uzoraka seruma. RNK VZN je otkrivena u 7/48 (14,6\%) uzoraka likvora i/ili seruma real time RT-PCR testom. IgM antitela češće su detektovana u likvoru od genoma VZN u likvoru ili serumu. Dokazivanje genoma VZN u likvoru kod ljudi ima ulogu dijagnostičkog testa za postavljanje konačne dijagnoze neuroinvazivnog oboljenja izazvanog VZN. No, značaj detekcije genoma je ograničen zbog niskog nivoa viremije u vreme kada bolest postane manifesna. S druge strane, IgM ELISA test koji je češće pozitivan u likvoru od RNK ima ograničenja kao: ukrštenu reaktivnost $s$ drugim flavivirusima i mogućnost duge perzistencije u likvoru i serumu.

Ključne reči: West Nile virus, ELISA IgM test, likvor, serum, real time RT-PCR, genom WNV

\section{INTRODUCTION}

The West Nile virus (WNV) is an arbovirus (arthropod-borne virus), the member of the family Flaviviridae, genus Flavivirus. WNV is widely distributed across Africa, Europe, Asia, Australia, and America among mosquitoes and vertebrates including humans and horses. Birds, as main reservoir, and mosquitoes (primarily Culex species) as vectors play a central role in transmission cycle of WNV in nature. Humans, equines and other animals are generally considered the "dead end" hosts because they have low viremia levels, insufficient to sustain transmission from vertebrate to feeding mosquitoes. Most WNV infections in humans remain asymptomatic. In one of four cases of WNV infection, WNV fever is developed (Petersen et al., 2013). In 1\% of cases, infection may result in West Nile neuroinvasive diseases (WNND) such as meningitis, encephalitis, poliomyelitis- as a condition with flaccid paralysis, with permanent neurological consequences or lethal outcome. Estimated percentages of WNND are as following: meningitis 35 - 40\%, encephalitis 55-60\% and poliomyelitis $5-10 \%$ (Sejvar et al., 2007). Clinically, WNV meningitis is indistinguishable from aseptic meningitis caused by other neurotropic viruses. 
WNV encephalitis is usually associated with seizures, mental status changes, focal neurologic deficits or movement disorders.

Until 1996, West Nile virus was not considered significant human pathogen because most reported infections were mild febrile disease in rural populations and a few cases of WNND were reported. WNV acquired neurotropism during the second half of the 20th century and two events occurred: outbreaks of WNND in Europe and introduction of WNV in The United States. In 1996, first explosive epidemic of WNND occurred in Europe. It was an epidemic in Romania in Bucharest, with 393 patients with chronologically confirmed or probable WNV infection, of whom 352 had acute central-nervous-system infections. Seventeen patients (5\%) older than 50 years died (Tsai et al., 1998). WNV had never been detected in the Western Hemisphere of America until August 1999, when the first cases of WNV infection appeared in New York City. In the outbreak in New York City, 59 people were infected and $63 \%$ of them had clinical signs of encephalitis, and seven patients died (12\%) (Nash et al., 2001). In 1999, explosive epidemic of WNV occurred in Volgograd City, Russia, on the bank of Volga River, where WNV infection has never been detected before. 826 patients were admitted to hospitals with invasive forms of the infection (acute aseptic encephalitis, meningitis) or fever. Case fatality rate was high. Out of total 84 cases of acute aseptic meningoencephalitis, 40 (48\%) were fatal (Platonov et al., 2001). At the beginning of $21^{\text {st }}$ century, outbreaks of WNND continued to occur in Europe. Outbreaks of WNND were recorded in different areas of Greece, Italy, Romania, Hungary, Serbia (ECDC, 2017). Sporadic cases were recorded in Spain, Portugal, Austria and Croatia (Vilibić-Čavlek et al., 2013). In Asia and Africa where WNV has been endemic for many years, WNV encephalitis occurs in children and has benign course and good prognosis. In Europe and USA, where WNV emerged only recently, WNV encephalitis is a severe disease and many of the survivors are left with severe neurologic deficits and cognitive dysfunctions.

\section{MATERIAL AND METHODS}

During the period from 2013 - 2016, 114 samples of cerebrospinal fluid and 107 serum samples were taken from 114 patients suspected of neuroinvasive form of WNV infection (WNND). Seven serum samples were not available from the patients. All patients were hospitalized at the Clinic for Infectious Diseases, Clinical Center of Vojvodina. At the Department of Virology of the Institute of Public Health of Vojvodina, WNV IgM and IgG ELISA (Enzyme linked immunosorbent assay) were applied for the detection of WNV-specific 
IgM and IgG antibodies in cerebrospinal fluid and in sera samples. Tests were performed according to manufacturer's instructions (Euroimmun, Germany). In total, 48 samples of cerebrospinal fluid or/and serum of people suspected of WNV infection were examined using commercial molecular tests - real time RT-PCR (real time reverse transcription - polymerase chain reaction (RT-qPCR) (WNV Real-TM, Sacace biotechnologies, Italy).

\section{RESULTS}

During the 2013 season, 37 samples of cerebrospinal fluid and 33 serum samples from 37 patients suspected of neuroinvasive form of WNV infection were collected and tested using commercial WNV IgM and IgG ELISA tests. IgM antibodies against WNV were present in 43.2\% (16/37) of CSF samples (Table 1). Serological study revealed that out of these $16 \mathrm{IgM}$ positive CSF samples, $81.2 \%(13 / 16)$ had IgM antibodies in serum samples too, and $2(12.5 \%)$ had no WNV - specific IgM response in the serum. In one case $6.2 \%(1 / 16)$ serum sample was not available. Out of the 16 cases of IgM positive serum samples, 3 (18.75\%) were not positive for IgM antibodies in CSF. IgG antibodies against WNV were detected in 4 out of $37(10.8 \%)$ samples of CSF and in 6 out of $33(18.2 \%)$ tested serum samples. All cases with WNV IgG antibody positive CSF samples were also tested IgG antibody positive in serum sample. West Nile virus RNA was detected by real time RT-PCR test in 6 out of $28(21.4 \%)$ tested CSF samples. Out of 6 cases with WNV RNA positive CSF, 4 (80.0\%) cases had WNV RNA in serum sample too. In 4 out of $6(80.0 \%)$ WNV RNA positive cases, IgM antibodies against WNV were detected simultaneously in the serum and in CSF sample. One of 6 human cases with detected WNV RNA in CSF had IgM antibodies only in serum samples and one had IgM antibodies only in sample of CSF. None of the WNV RT-PCR positive cases had IgG antibodies in the serum or in CSF.

During the 2014 season, 35 samples of CSF and 33 serum samples were collected from 35 patients and tested by ELISA test. IgM antibody positive results in CSF were obtained in 8.6\% (3/35) patients. Two of three IgM antibody positive patients $(66.7 \%)$ had IgM antibodies in samples, CSF and serum, and one patient (33.3\%) had IgM antibodies in CSF only. Three out of 33 (9.1\%) serum samples were WNV IgM antibody positive. None of the CSF samples were positive for WNV IgG antibodies. In total, WNV IgG antibodies were detected in three out of $33(9.1 \%)$ serum samples. 
Table 1. Frequency of WNV IgM positive cerebrospinal fluid/serum sample and presence of WNV RNA in patients suspected of neuroinvasive form of WNV infection

\begin{tabular}{|c|c|c|c|c|c|c|}
\hline \multirow{2}{*}{ 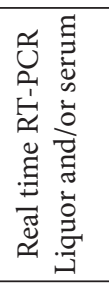 } & $\therefore$ & $\stackrel{\vec{H}}{\vec{\sim}}$ & 合 & $\stackrel{\infty}{+}$ & 0 & $\begin{array}{l}0 \\
\underset{+}{-}\end{array}$ \\
\hline & $\underset{\jmath}{z}$ & 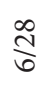 & 学 & $\underset{\beth}{\beth}$ & Iิ & $\stackrel{\infty}{\stackrel{\infty}{R}}$ \\
\hline \multirow{2}{*}{ 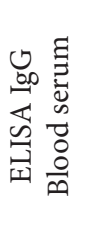 } & $\therefore$ & ֵ & $\vec{a}$ & $\stackrel{n}{a}$ & ir. & $\stackrel{\sim}{\exists}$ \\
\hline & $\underset{z}{z}$ & $\stackrel{\Re}{\varrho}$ & $\frac{m}{m}$ & $\underset{\mathrm{N}}{\overrightarrow{\mathrm{N}}}$ & $\stackrel{\mathrm{I}}{\leftrightarrows}$ & 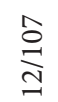 \\
\hline \multirow{2}{*}{ 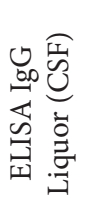 } & $\therefore$ & $\stackrel{\infty}{\stackrel{\infty}{\Theta}}$ & 0 & 0 & 0 & $\stackrel{n}{m}$ \\
\hline & z & $\hat{\stackrel{\beta}{\gamma}}$ & $\stackrel{n}{\delta}$ & 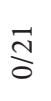 & $\overrightarrow{\mathrm{J}}$ & $\underset{\ngtr}{\stackrel{J}{F}}$ \\
\hline \multirow{2}{*}{ 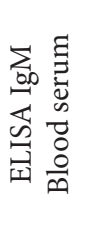 } & $a^{\circ}$ & 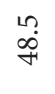 & $\ddot{a}$ & $\vec{\infty}$ & 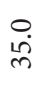 & $\stackrel{\infty}{\dot{m}}$ \\
\hline & ż & 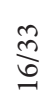 & $\frac{m}{m}$ & $\frac{\vec{\Delta}}{\infty}$ & 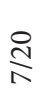 & $\underset{\mathrm{f}}{\stackrel{ }{f}}$ \\
\hline \multirow{2}{*}{ 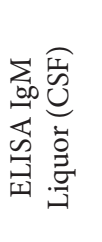 } & $\therefore$ & $\stackrel{\sim}{\not}$ & $\underset{\infty}{\infty}$ & $\stackrel{\circ}{\circ}$ & $\begin{array}{l}0 \\
\stackrel{d}{i}\end{array}$ & 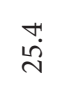 \\
\hline & z & $\stackrel{0}{\underline{0}}$ & $\stackrel{n}{m}$ & $\overrightarrow{\mathcal{H}}$ & $\overrightarrow{\mathrm{J}}$ & $\underset{\text { ন }}{\stackrel{ \pm}{ন}}$ \\
\hline \multicolumn{2}{|c|}{ 节 } & ते & $\overrightarrow{\mathrm{N}}$ & $\stackrel{\sim}{\vec{N}}$ & 号 & 氶 \\
\hline
\end{tabular}

Legend: $\mathrm{n}$ - number of positive samples; $\mathrm{N}$ - total number of samples; $\%$ - percentage of positive samples; ND not done 
During the 2015 season, testing for WNV infection was performed on 21 patients with suspected WNND. In total, 21 samples of CSF and 21 serum samples were tested applying serological and molecular tests. In CSF samples testing WNV IgM ELISA was found to be positive for 4 patients out of 21 (19.0\%). All these patients also reacted positive for WNV IgM antibodies in serum samples. The WNV IgM ELISA was positive for $38.1 \%(8 / 21)$ serum samples of the patients with suspected WNND. The WNV IgG ELISA were found negative for all CSF samples, however, two serum samples $(2 / 21)$ were tested positive. The WNV RNA was detected in sample of CSF of only one patient.

During the season 2016, in total 21 samples of CSF and 20 serum samples were collected from 21 patients with suspected WNND. The WNV IgM antibodies were detected in CSF of 6 patients (28.6\%). Out of 20 patients' serum samples tested with WNV IgM ELISA, 7 (35\%) were found to be IgM antibody positive. None of the samples of CSF tested positive for WNV IgG antibodies, but those antibodies were detected in 1 out of 20 (5.0\%) tested serum samples.

\section{DISCUSSION}

Various methods are available for detecting viable WNV, WNV antigen or WNV RNA in human diagnostic samples. The viable WNV can be detected by isolation on cell culture (e.g. Vero cell) or in the brain tissue samples from the laboratory infected suckling mice. Disadvantages of virus isolation are that the method is time-consuming and it requires the use of cell cultures and handling with live, infectious virus and BSL-3 (Biosafety level 3) facility. For virus genome detection and amplification molecular techniques such as real time reverse transcription polymerase chain reactions (real time RT-PCR) and nucleic acid sequence based amplification (NASBA) methods are applied. The WNV genome RNA can be detected in human CSF, serum and other tissues. Molecular methods have great sensitivity but limited utility in diagnosing human WNV neuroinvasive disease, which is due to the low level of viremia present in most cases at the time of clinical presentation. Isolation of the virus has similarly limited significance in the diagnosis of WNND. Molecular methods and virus isolation are useful only at the beginning of the infection. The best choice at the later stages of illness are serologic methods. The serological screening method for laboratory diagnosis of human WNND is the ELISA IgM antibody assay. ELISA is the most widely used serological method because it is sensitive and easy to perform in routine practice in a diagnostic virology laboratories. In this study, IgM antibodies against WNV were detected in $31.8 \%$ 
of tested serum samples from suspected WNND patients. According to the results of many studies, IgM antibodies against WNV can persist in serum for months (Papa et al., 2015). Murray detected immunoglobulin M antibodies up to 8 years after infection with WNV in a study encompassing 163 participants (Murray et al., 2013). In the study of Roehrig at al. (2003), 60\% of patients with laboratory - confirmed WNV encephalitis had WNV IgM antibodies approximately 500 days after onset of the disease. Because of that, detection of WNV IgM antibodies in blood sera should not be considered a marker of acute West Nile virus infection and determination of avidity of WNV IgG is necessary to ensure the accurate and reliable diagnosis (Hrnjaković et al., 2017a). The presence of IgM antibodies in CSF establishes the diagnosis of WNND since IgM antibody does not cross the blood-brain barrier. The IgM antibodies appear in CSF within 8 days of the beginning of disease in at least $90 \%$ of patients with encephalitis or meningitis (Petersen et al., 2013). They are marker of acute CNS infection. In our study, IgM antibodies were found in CSF in 29 of 114 (25.43\%) patients suspected of neuroinvasive form of WNV infection. Molecular methods are better marker of WNND but positive results can be established only at the beginning of diseases. In this study, genomic RNA of WNV was detected in $14.6 \%$ serum or/and CSF samples by real time RT-PCR. According to the study of Kapoor et al. (2004), the presence of IgM antibodies in CSF may not always reflect the acute phase of infection with WNV. These authors detected WNV IgM-specific antibodies in CSF specimens from the three patients with CNS disease persisting for 110, 141, and 199 days of post-acute phase of infection. The other problem associated with serological diagnosis of flavivirus infections is the cross-reactivity between different members of genus Flavivirus including Sent Louis encephalitis virus - SLEV, Japanese encephalitis virus - JEV, Yellow fever virus - YFV and Denga 1-4 viruses. According to the results of other serological studies, Tick-borne encephalitis virus - TBEV (Hrnjaković et al., 2016) and Usutu virus - USUV (Hrnjaković et al., 2017b) co-circulate in humans in Vojvodina and because of that, misinterpretation of serological results is possible. The issue of cross-reactivity may be overcome by performing the plaque reduction neutralization test (PRNT). PRNT is the gold standard for the serological diagnosis of flaviviral infections. Disadvantages of this test are that it requires facilities that are available only in specialized research institutions (BSL-3 laboratories). In this study, PRNT was not used as confirmatory assay and it was the limitation of this study.

In 2010, WNV RNA genome was detected in mosquito Culex pipiens collected in the city of Novi Sad applying real time RT PCR (Petrić et al., 2012). Circulation of WNV in wild birds in Vojvodina was also detected by using 
molecular methods and serological tests. The WNV isolate from wild birds belonged to the lineage 2 and clustered with WNV strains isolated in Hungary 2004, Greece 2010 and Italy 2012 (Petrović et al., 2013). Circulation of WNV in pigs, boars and roe deer was also detected in Serbia using molecular methods and serological tests (Escribano-Romero et al., 2015). The first human cases of WNND on the territory of South Bačka district in Vojvodina Province of Serbia were registered in 2012. It was the first epidemic in South Bačka district with 32 patients in which neuroinvasive form of WNV infection was diagnosed. All patients were hospitalized at the Clinic for Infectious Disease of the Clinical Center of Vojvodina in Novi Sad. The largest number of patients has recovered completely. In $6.25 \%$ of patients, sequelaes were developed. Lethal outcome was registered in 3.13\% cases (Sević et al, 2015). Since 2013, human WNV infections on the territory of South Bačka district have been diagnosed every year from July to October at the Institute of Public Health of Vojvodina. Complete genome sequences of the WNV isolate from a human patient with neuroinvasive disease, resident of Novi Sad, were described (Jovanović Galović et al., 2017). It was the first whole genome sequencing of the isolate from human sample in Serbia. The isolate belonged to lineage 2 and similarities with strains circulating in Greece, Hungary, Austria, and Italy were demonstrated (Jovanović Galović et al., 2017).

\section{CONCLUSION}

WNV has the ability to cause neuroinvasive disease (WNND) that can result in debilitating morbidities and long-term sequelaes. WNV RNA detection in CSF or serum is confirmatory diagnostic test but has limited utility in the diagnosis of WNV neuroinvasive disease due to low viremia level at the time of clinical presentation of disease. Diagnosis of WNND usually relies on detection of IgM antibodies in serum or cerebrospinal fluid. Special emphasis in diagnosing of WNV infection should be put on CSF analyses (IgM ELISA and RT-PCR).

\section{ACKNOWLEDGMENT}

This work was financed by the Ministry of Education, Science and Technological Development, Republic of Serbia - projects TR31084 and III43007 


\section{REFERENCES}

1. ECDC: Disease data from ECDC Surveillance Atlas. Historical data by year. Available on line: https://ecdc.europa.eu/en/west-nile-fever/surveillance-and-disease-data/historical, 2017

2. Escribano-Romero E., Lupulović D., Merino-Ramos T., Blázquez A.B., Lazić G., Lazić S., Saiz J.C., Petrović T.: West Nile virus serosurveillance in pigs, wild boars, and roe deer in Serbia. Veterinary Microbiology, 176, 3-4, 365-369, 2015.

3. Hrnjaković Cvjetković I., Cvjetković D., Patić A., Radovanov J., Kovačević G., Milošević V.: Infekcije virusom krpeljnog meningoencefalitisa kod ljudi. Medicinski Pregled, 69, 3-4, 93-98, 2016.

4. Hrnjaković Cvjetković I., Radovanov J., Kovačević G., Patić A., Nataša N., Milošević V.: Significance of IgG avidity test in diagnosis of West Nile virus infection. Medicinski Pregled, 70, 11-12, 395-401, 2017 a.

5. Hrnjaković Cvjetković I., Petrović T., Petrić D., Milošević U., Radovanov J., Kovačević G., Jovanović Galović A., Patić A., Nikolić N., Cvjetković D., Stefan Mikić S., Milošević V.: Usutu virus an emerging flavivirus in Europe. Arhives of Veterinary Medicine, 10, 1, 25 -35, 2017b.

6. Jovanović Galović A., Weyer J., Jansen van Vuren P., Paweska J.T., Radovanov J., Kovačević G., Hrnjaković Cvjetković I., Petrović V., Blumberg Lucille H., Milošević V.: West Nile Virus Lineage 2 Associated with Human Case in Republic of Serbia. Vector-Borne and Zoonotic Diseases, 17, 11, 780-783, 2017.

7. Kapoor $H_{.}$, Signs $K_{\bullet}$, Somsel P., Downes F.P., Clark P.A., Massey J.P.: Persistence of West Nile Virus (WNV) IgM antibodies in cerebrospinal fluid from patients with CNS disease. Journal of Clinical Virology, 31, 4, 289-291, 2004.

8. Murray K.O., Garcia M.N., Yan C., Gorchakov R.: Persistence of detectable immunoglobulin $\mathrm{M}$ antibodies up to 8 years after infection with West Nile virus. American Journal of Tropical Medicine and Hygiene, 89, 5, 996-1000, 2013.

9. Nash D., Mostashari F., Fine A., Miller J., O’Leary D., Murray K., Huang A., Rosenberg A., Greenberg A., Sherman M., Wong S., Layton M.:1999 West Nile Outbreak Response Working Group: The outbreak of West Nile virus infection in the New York City area in 1999. The New England Journal Medicine, 344, 24, 1807-1814, 2001.

10. Papa A., Anastasiadou A., Delianidou M.: West Nile virus IgM and IgG antibodies three years post- infection. Hippokratia, 19, 1, 34-36, 2015.

11. Papa A., Danis K., Athanasiasdou A., Delianidou M., Panagiotopoulos T.: Persistence of West Nile virus immunoglobulin $\mathrm{M}$ antibodies, Greece. 
Journal of Medical Virology, 83, 10, 1857-1860, 2011.

12. Petersen L.R., Brault A.C., Nasci R.S.: West Nile virus: review of the literature. Journal of the American Medical Association, 310, 3, 308-315, 2013.

13. Petrić D., Hrnjaković Cvjetković I., Radovanov J., Cvjetković D., Jerant Patic V. , Milošević V., Kovačević G., Zgomba M., Ignjatović Cupina A., Konjević A., Marinković D., Paz Sanchez-Seco.: West Nile virus surveillance in humans and mosquitoes and detection of cell fusing agent virus in Vojvodina Province (Serbia). Health MED, 6, 2, 462-468, 2012.

14. Petrović T., Blazquez A.B., Lupulovic D., Lazic G., Escribano-Romero E., Fabijan D.M., Kapetanov M., Lazic S., Saiz J.: Monitoring West Nile virus (WNV) infection in wild birds in Serbia during 2012: first isolation and characterization of WNV strains from Serbia. Euro Surveillance, 18, 44, pii: 20622, 2013.

15. Platonov A.E., Shipulin G.A., Shipulina O.Y., Tyutyunnik E.N., Frolochkina T.I., Lanciotti R.S., Yazyshina S., Platonova O.V., Obukhov I.L., Zhukov A.N., Vengerov Y.Y., Pokrovski V.I.: Outbreak of West Nile Virus infection, Volgograd region, Russia, 1999. Emerging Infectious Diseases, 7, 1, 128-132, 2001.

16. Roehrig J.T., Nash D., Maldin B., Labowitz A., Martin D.A., Lanciotti R.S., Campbell G.L.: Persistence of virus-reactive serum immunoglobulin $\mathrm{M}$ antibody in confirmed West Nile virus encephalitis cases. Emerging Infectious Diseases, 9, 3, 376-379, 2003.

17. Sejvar J.J.: The long-term outcomes of human West Nile virus infection. Clinical Infectious Diseases, 44, 12, 1617-1624, 2007.

18. Sević S., Stefan-Mikić S., Šipovac D., Turkulov V., Milošević V., Hrnjaković Cvjetković I.: Epidemics of the central nervous system infections caused by West Nile virus in the territory of the South Bačka District, Vojvodina, Serbia. Vojnosanitetski pregled, 72, 12, 1098-1104, 2015.

19. Tsai T.F., Popovici F., Cernescu C., Campbell G.L., Nedelcu N.I.: West Nile encephalitis epidemic in southeastern Romania. Lancet, 352, 9130, 767$771,1998$.

20. Vilibić-Čavlek T., Barbić L., Ljubin-Sternak S., Pem-Novosel I., Stevanović

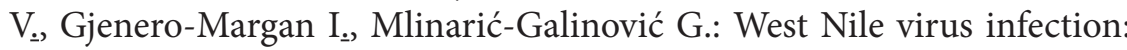
re-emergent disease in Croatia. Lijecnicki Vjesnik, 135, 5-6, 156-61, 2013.

Primljeno: 08.06.2018.

Odobreno: 11.08.2018. 
